PAedAGogia ChristianA

2/24 (2009) - ISSN 1505-6872

Maria Matgorzata Boużyk*

Warszawa

\title{
Czy filozofia może za-szkodzić nauczycielowi? Kilka uwag o zagubionej tożsamości czlowieka i filozofii
}

Mimo że sama jestem filozofem i od wielu lat uczę filozofii w kilku warszawskich uczelniach, mimo że mam wielkie umiłowanie tej dziedziny wiedzy i z wielkim szacunkiem myślę o tych, którzy mnie wprowadzali w piękno myślenia filozoficznego, to wiem, że filozofia może też wprowadzać nie zawsze twórczo piękny niepokój w umysł człowieka. Jako miłość mądrości, wyraża ona dogłębne ludzkie pragnienie zbliżenia się do tajemnic bytu, ale jako ludzki wysiłek jest narażona na to wszystko, co wiąże się z ludzką natura, to jest z przygodnością (por. FeR 6). Zapominanie o tych dwóch współrzędnych w pracy badawczej wtłacza filozofa w minimalizm i w pychę, a z rezultatów jego pracy czyni niebezpieczną mitologię. Taka filozoficzna teoria rzeczywistości, o ile staje się (niekoniecznie świadomie!) inspiracją dla innych typów wiedzy i nauki (humanistyki), a czego od niej jako od wiedzy naukowej można oczekiwać, miewa tragiczne konsekwencje kulturowe (w wymiarze jednostkowego życia człowieka, jak i całych ludzkich społeczności) ${ }^{1}$. „Nieznaczne odchylenie od prawdy, popełnione na samym początku, rośnie do rozmiarów dziesiątków tysięcy, w miarę jak postępuje badanie"2. Tak pisał Arystoteles w IV wieku p.n.e. Weryfikacją tego są historie poszczególnych osób i narodów, bo mądrość, na której ludzie opierają swoje życie, daje owoc w ich działaniach.

* Dr Maria Małgorzata Boużyk, adiunkt w Katedrze Pedagogiki Kultury i Edukacji Międzykulturowej Uniwersytetu Kardynała Stefana Wyszyńskiego w Warszawie.

${ }^{1} \mathrm{O}$ relacjach między poszczególnymi typami nauk o człowieku oraz różnymi typami wiedzy (nauka, wiara, światopogląd, ideologia) zob. artykuły S. Kamińskiego: (1) Typy ludzkiej wiedzy oraz (2) Naukowa, filozoficzna i teologiczna wizja człowieka, w: tenże, Jak filozofować?, Lublin 1989, s. 13-32, 279-292.

${ }^{2}$ Arystoteles, O niebie, Warszawa 1980, s. 14. 
Dla uzasadnienia swojej tezy podejmę krótką refleksję nad poznaniem naukowym i sensem uprawiania filozofii. Niech dwa pytania wyznaczą moje rozważania: czy nauka może zaszkodzić człowiekowi i jakie jest miejsce filozofii we współczesnej kulturze?

\section{Czy nauka może szkodzić czlowiekowi?}

Pytanie brzmi dosyć prowokacyjnie, jednak jego sens uzasadnia i sama historia nauki, i sytuacja egzystencjalna człowieka. Z jednej strony mamy do czynienia z wieloma wydarzeniami z dziejów kultury, gdzie ludzie nauki, zazwyczaj nie wprost, gotowali innym los nie do pozazdroszczenia. Naukowca interesuje przecież prawda, a jej relacja do dobra moralnego i piękna ludzkiego oblicza nie zawsze bywa oczywista. Dlatego naukowiec łatwo zamyka się w ciszy swego laboratorium pracy badawczej, sal wykładowych, przez które w swoim życiu przemierza naukowo, czy książek, które czyta sobie i pisze sobie. Naukowiec, jak każdy człowiek, istnieje sobie.

$\mathrm{Z}$ drugiej strony nauka, która jest dziełem tylko człowieka, nie wyrasta ontologicznie ponad status ontologiczny swojego autora. Jednym słowem, jest na miarę człowieka, a człowiek, jakkolwiek jest niezwykłym stworzeniem, to ma swoje ograniczenia. Ontycznie jest zawsze przygodny, niezależnie od tego, czy wygenerowała go ślepa ewolucja, czy czuła ręka Boga. Pozostawiam na boku bajki-mity o narodzeniach człowieka i bogów, gnostyckie teksty zmieniające sens znanych słów. W bajkach, jak to w bajkach, działają zaklęcia, są złe i dobre wróżki, kierowane ręką autora baśniowej opowieści czy krwawego horroru. Pomysłowość bajarza zawsze może dogodzić słuchaczowi jakimś zakończeniem historii ludzkiej.

A filozof? Możne oczywiście dyskutować teoretycznie nad tym, co jest bardziej smutne: przygodność ewolucji czy ludzkich wad. Praktyka codzienności przemawia natomiast faktami bez żadnej kokieterii. Zaspokojony głód zwierzęcia przestaje być groźny. Jeśli zdrowego najedzonego drapieżnika nie przestraszymy swoją obecnością, to nas nie zaatakuje. Człowiek w obydwu sytuacjach może nie mieć dosyć. Je bez końca i potrafi kipieć od gniewu agresją. Jak poznaje, by poznawać, jak kocha, by kochać, tak też je, by jeść, atakuje, by atakować. Dlaczego? Filozofia wyjaśnia to zdolnością do transcendowania, która jest związana z sytuacją bytową człowieka, z jego duchowością i rozumną duszą - elementem jego struktury bytowej (kreacjonizm).

Filozofowie jeszcze w zamierzchłych czasach mawiali, że ludzkie działanie jest na miarę ludzkiego bytu, a więc nie może być bardziej doskonałe i niedoskonałe niż sam człowiek. W stwierdzeniu tym nie chodziło o podważanie możliwości rozwoju osoby ludzkiej w kierunku pełni człowieczeństwa, ale pokazanie granic i tajemnic ludzkiego bytu i bytu w ogóle. Przed tymi tajemnicami człowiek staje często zdumiony, zaniepokojony i ich przekroczyć (pominąć) nie zdoła, bo one są wpisane w jego ontyczną przygodność (tę w opisie ewolucyjnym bądź stwór- 
czym). Ta przygodność daje o sobie znać we wszystkich działaniach kulturowych człowieka, w tym w jego poznaniu potocznym i naukowym. Najprostszym przykładem jest tu sam fakt rozwoju poznania, tak w wymiarze poszczególnych osób, jak i historii ludzkości, na której kartach już przed dwudziestoma siedmioma wiekami zaczęliśmy zapisywać pierwsze wyniki badań naukowych. Niemniej ani wtedy, ani dziś wiedza nie jest nam dana w sposób gotowy. Udziałem naukowców był, jest i będzie trud odkrywania rzeczywistości, której wielkie bogactwo ciaggle staje przed ciekawością umysłu i serca w nowym kształcie starych pytań. O co pytamy rzeczywistość? Po co trudzimy się poznawczo od tylu wieków?

Odpowiedź jest prosta: by pewniej kroczyć po Ziemi, istnieć w kosmosie. Co czuje jednak ewolucjonista, gdy umiera, co czuje pedagog, który na tej teorii zbudował swój program wychowania? Co czuje nauczyciel, który zostawia ludzkość i ginie w nicości pokoleń? Co ma zrobić wychowanek, który po śmierci nauczyciela jeszcze żyje? Dla czego żyje wychowanek-ewolucjonista? Czym jest altruizm, służba, prawda, dobro, piękno w tej optyce wyjaśniania rzeczywistosci? Co różni ją od optyki kreacjonistycznej? Czym jest chrześcijańska pedagogika? Jaka jest jej rola we współczesnej kulturze rodzenia człowieka?

Status bytowy człowieka nie gwarantuje poznającemu człowiekowi możliwości przenikania rzeczywistości umysłem w sposób nie-ludzki. Ludzkie poznanie jest aspektywne, dokonuje się w czasie i jest związane rzeczywistością. Naukowiec będąc człowiekiem, mimo całej troski o swój warsztat badawczy, staje wobec świata tylko jako człowiek. Składanie obrazu prawdy bytu z prawd cząstkowych, uzyskiwanych przez całe wieki wysiłku naukowego poznania, uczyły człowieka-badacza pokory. Imponujący rozwój przyrodoznawstwa uwiódł możliwościami. Jakość życia, która dzięki temu się zmieniła, jest powodem słusznej dumy człowieka. Jednocześnie w statusie ontycznym człowieka nic to nie zmieniło. Jest dalej przygodny. Wynikające z tej prawdy kolejne prawdy jest w stanie odsłonić tylko wiedza naukowa, która umie przekraczać skończoność kosmosu. Żadna z nauk przyrodniczych, formalnych, humanistycznych tego nie zrobi. Możliwość najgłębszego mówienia o transcendencji, o transcendentnej perspektywie ludzkiego życia i o teorii wychowania, która ku temu prowadzi, leży w gestii tylko dwóch nauk: teologii i filozofii metafizycznej. Filozofia musi mieć przy tym tak postawione pytanie badawcze, które pozawala mówić o rzeczywistości pozaświadomościowej Transcendencji - jej istnieniu i naturze (nie każda metoda filozoficzna to może!). Dlatego nauka w kulturze chrześcijańskiej nie zrezygnowała z osiagnięć Grecji i Rzymu. Nie zrezygnowała też ze Starego Testamentu.

Status bytowy człowieka także nie gwarantuje naukowcom, że ich intelektualna przygoda penetrowania rzeczywistości nie odbędzie się bez porażek. Bycie podmiotem poznającym jest oszałamiającą wartością! Człowiek czasem więc może zapomnieć o dialogu ze światem i z innymi osobami i może zacząć snuć własną opowieść, mniemając, że na tym polega jedność z rzeczywistością. Tracąc perspektywę swojego miejsca w świecie, staje się niczym bóg. Każe światu żyć według własnej miary. Gromadzi grono wyznawców. Włazi na ołtarz. 
Błąd poznawczy, fałsz potraktowany jak rzeczywistość, jest wliczony w ludzkie poszukiwania prawdy i stanowi nie tylko ryzyko dla zwykłego człowieka, ale i tych, którzy poprzez odpowiednio dobrane do aspektu badawczego metody i wspólną pracę starają się zapewnić rezultatom poznawczym pewność i obiektywną wartość, a tym samym zabiegają o wyrwanie ich z kręgu domniemań i nadanie im statusu wiedzy. Dlaczego?

Dwa elementy wyznaczające podmiotowość człowieka są zawsze kluczem do tego, co ludzkie. Wolność i rozumność (natura ludzka) zawsze opisują człowieka, bo wyjaśniają jego działanie. Bez tych dwóch elementów nie ma ludzkiego bytu. Grecy pisali o człowieku - duszy, człowieku - rozumnym zwierzęciu, człowieku - części kosmosu, który działa w sposób niezdeterminowany, ale poddany losowi, fatum, prawu kosmosu. Chrześcijaństwo, nie kwestionując tego dorobku, pokazuje Boga, który staje się człowiekiem, który umiera na krzyżu i który zmartwychwstaje. Trzy prawdy, które dla jednych są głupstwem, dla innych zgorszeniem.

Z chrześcijaństwem filozofia (poznanie naturalne) nie przestała istnieć. Jej (poznania naturalnego) wartość ma w tej kulturze zawsze ważne miejsce. Na przykład cały wysiłek filozofii średniowiecznej idzie w kierunku zrozumienia tych prawd, którymi kultura chrześcijańska żyje. Wiara potrzebuje zrozumienia. Bez prawdy nie ma też prawej woli i prawego działania. A tam, gdzie rozum człowieka nie daje sobie rady, jeśli nie wkroczy cisza Transcendencji, pojawią się mity. Dlatego naukowiec, który jest na drodze poszukiwań, który jest jednym z wielu naukowców kroczących po ścieżkach rzeczywistosci, potrzebuje oparcia w wierze. Bez skrzydła wiary duch ludzkiego rozumu odlatuje w sferę mitu lub głuchej frustracji, zgorzknienia. Człowiek staje się wtedy dziwnym męczennikiem własnej niemocy, własnych wyborów. Człowiek, jak mówi chrześcijaństwo, jest powołany do wolności, do przekraczania skończoności. Człowiek w swojej przyrodzoności (jedności psychofizycznej) jest nadprzyrodzonej natury (kreacjonizm).

Znana od starożytności wartość dialogu dla tworzenia przestrzeni wspólnej jest jedną z prawd, które ciagle zachowują wartość mimo upływu czasu. Człowiek w swym poznaniu transcenduje rzeczywistość (teza kreacjonizmu czy ewolucjonizmu?). Jednak to rzeczywistość odciska się w jego umyśle. W tym procesie jest całe uwarunkowanie bytowe człowieka (w transkrypcji każdej antropologii musi być jakoś nazwane!). By tworzyć przestrzeń kultury, niszy, w której żyjemy, potrzeba znaków, przez które się komunikujemy: naturalnych czy umownych? Mogę na przykład kichnąć. Zwierzę też kicha, ale tylko w filmie rysunkowym dla dzieci zasłoni swój nosek łapką, by nie zarażać innych zwierząt. Symbol wymaga umowy-porozumienia, w które jest wpisana wrażliwość na piękno rzeczywistości i na jej braki.

W kreacjonizmie także brak (jakim na przykład są cierpienia fizyczne, psychiczne itp.) jest sensowny, jest dobry, jest piękny. W braku może być obecna dusza człowieka. Przyjęcie braku, słabości, zatrzymanie na sobie zła, czyjegoś 
grzechu jest cierpliwym i cichym męstwem chrześcijan. Brak to okazja do najbardziej twórczego i pięknego odpowiadania na potrzeby drugiego człowieka. Na przełamywanie kastowości społeczeństw (na przykład praca - służba Matki Teresy z Kalkuty), na ból, cierpienie, na potrzebę-brak każdego innego bliźniego. W brakach świata jest miejsce na twórczość człowieka. Dlatego chrześcijańska kultura jest niewypowiedzianie piękna. Dlatego ona daje możliwość najdoskonalszego upiększania świata, tworzenia kultury. Dlatego ona nigdy nie odrzuca innych kultur, tylko je przenika. Jej wyjątkowość polega na tym, że nie tylko uniesienia, ale i smutki historii ludzkiej, tej indywidualnej i tej zbiorowej mówią do nas językiem sensów. Ona rodzi zawsze nowego człowieka. Badania prowadzone nad francuskimi i niemieckimi noworodkami pokazały, że dzieci uczą się języka rodziców już w łonie matki. Podobno noworodki płaczą z akcentem języka narodowego rodziców!

Człowiek może błądzić, a jego proces poznawczy jest swoistą „drogą”. Jeśli tak, to sytuacja, w której jakiś fałsz zaczyna grać rolę prawdy, jest nie do uniknięcia. Jednakże nie jest to wydarzenie obojętne dla samego człowieka. Ludzkie poznanie można porównać do „okna na świat”. Jest procesem, w którym człowiek bogaci się o poznawaną rzeczywistość. Arystoteles powiedział to jeszcze mocniej! Zauważył mianowicie, że, poznając, człowiek staje się tą rzeczywistością, w tym sensie doskonali się, zostaje ,powiększony” o zinterioryzowaną rzeczywistość, dlatego staje się silniejszy (to jest mądrzejszy) ${ }^{3}$. Co dzieje się w człowieku w przypadku uznania za prawdę czegoś, co wcale nią nie jest, a więc w przypadku, gdy naukowiec w pochopnym uogólnieniu, w ekstrapolacji tezy na obszary niepodpadające pod badany obszar, tworzy sądy, teorie, którym przypisuje wartość prawdy?

Dziś logika wyróżnia całą gamę błędów logicznych ${ }^{4}$. Jednak nawet u początków nauki ludzie rozumieli sytuację wartościowego poznania, które jest informatorem o rzeczywistości, i takiego, które nim nie jest. Dlatego tylko wiedzę nazwali cnota, a o mniemaniu czy wierze mówili jako o poznaniu mniej wartościowym, nieusprawniającym w pełni (nierozwijającym) człowieka. Mniemanie (dziś powiedzielibyśmy: opinia lub hipoteza badawcza) jest stanem poznania, w którym jak gdyby stoimy jeszcze na rozwidleniu dróg, wahając się, którędy iść dalej. Możemy sprawdzać, szukać. Stan poznawczej niepewności, o ile wzięty w jego celowości, jest bardzo twórczy, a przez to ludzki, czyli manifestujący wolność, którą mamy. W przeciwieństwie do niego, zaktualizowane poszukiwanie jest już wiedzą, która pozwala nam pewnie iść jedną z dwóch dróg. Dzięki wiedzy gromadzonej przez wiele pokoleń kultura Europy otwierała przestrzenie zamknięte dla innych cywilizacji.

3 Arystotelesowska wypowiedź „Dusza poznając - staje się wszystkim” w filozofii Tomasza z Akwinu nabrała nowego znaczenia. Zob. STh, q. 1, art. 84-89. Komentarz do tekstów obydwu autorów - zob. M. A. Krąiec, Ja-człowiek, Lublin 1991, s. 211.

${ }^{4}$ Zob. S. Kamiński, Systematyzacja typowych błędów logicznych, w: tenże, Metoda i język, Lublin 1994, s. 199-230. 
Co jest niebezpieczne dla nauki? Wiara. Wiara jest wyborem drogi, ale wyborem, za którym stoi tylko przekonanie, budowane w oparciu o autorytet (nawet naukowy!) czy jakieś praktyczne, osobiste korzyści. Przekładając powyższe porównanie na język metodologii nauk, powiemy, że skoro każdy sąd ma jedną z dwóch wartości logicznych: prawdę lub fałsz, czyli skoro nie może być zarazem prawdziwy i fałszywy, to wiedza jest uzgodnieniem się z rzeczywistościa, czyli poznaniem prawdy, opinia, sytuacją, gdy jeszcze nie można rozstrzygnąć o prawdziwości czy fałszywości sądu, a wiara to wprowadzenie w obszar poznania czynnika pozaracjonalnego (czynnika woli), pod którego wpływem rozum uznaje jakiś sąd za prawdziwy, mimo że nie ma ku temu żadnych podstaw 5 .

Dla poznania potocznego (nienaukowego) wiara i opinia są stanami poznawczymi naturalnymi, bo wyrastają z ontycznej struktury człowieka. Często jest tak, że człowiek może wygłosić tylko opinię, ale oparcie całego życia tylko na opinii, która nie daje wiedzy, jest sprawą życia w totalnej niepewności i w sumie musi prowadzić do jakiegoś zniechęcenia, zagubienia, poczucia niespełnienia czy braku szczęścia. Dlatego tyle sytuacji zawierzenia w ludzkim życiu i dogmatycznego wybrania jednej z dwóch opcji, jeśli brak wiedzy, jeśli brak prawdy.

Dla poznania naukowego wiara jest poznawczo nieciekawa. Wynika to ze statusu poznania naukowego, które chociaż wyrasta z poznania potocznego (naukowiec to też człowiek), dąży jednak do eliminowania z niego wszystkich czynników pozapoznawczych (woli i uczuć), by nie wpływały na wynik poznania. Poznanie naukowe w stosunku do poznania religijnego zachowuje natomiast pełna autonomię $\mathrm{z}$ racji tego, że jest poznaniem naturalnym, a nie tym, które opiera się na Objawieniu. Opinia natomiast, w kształcie hipotezy, może być wprowadzona w procedurę badawczą, ale zanim zacznie być wiążąca, musi zostać poddana rozważeniu, które wymaga sprawdzenia. Nie ma w niej pochopnej dowolności, która bywa udziałem człowieka poza obszarem nauki6.

Naukowcy i wytwór ich poznania (nauka), z racji tej troski, ostrożności w poznaniu, od wieków cieszyli się w kulturze europejskiej zasłużoną estymą. Absolutyzowanie jednak owej sytuacji, występujące szczególnie w czasach nowożytnych, uczyniło z nauki coś na kształt bożka, w którego nieomylność zaczęto ufać bezgranicznie i dopiero różne tragiczne wydarzenia kultury współczesnej kazały zapytać o fenomen niewoli rozumu (zob. FeR 45-48, 75-79). Dla ludzi odpowiedzialnych za współczesną kulturę to pytanie może jest jednym z najtrudniejszych, z którym muszą się zmierzyć. Oświeceniowy racjonalista bywa strasznym uparciuchem. Czy w wersji idealistycznej, czy pozytywistycznej wie czasem lepiej niż Bóg, jak być człowiekiem. Staje się stwórcą siebie. Jest duchem lub rewolucjonista, jest romantykiem lub pozytywista, jest sentymentalny lub heroicznie racjonalny, jest nadmiernie smutny lub nadmiernie wesoły. Nie jest nowym człowiekiem, ale pesymistycznym optymistą - optymistycznym pesymistą.

\footnotetext{
${ }^{5}$ Zob. tenże, Typy ludzkiej wiedzy.

${ }^{6} \mathrm{O}$ tych relacjach nauki, opinii i wiary zob. tamże.
} 
Lubi wymierzać sprawiedliwość, urządzać świat według oświeconego rozumu. Niszczy inne kultury, tworząc nowy porządek. Z czułością wiedzącego lepiej, jaki ma być człowiek. Innego zamyka w rezerwatach, obozach koncentracyjnych czy łagrach. Wszystko w imię prawdy, wolności i braterstwa.

Osoby rozumiejące rolę filozofii w kształtowaniu koncepcji nauki, w tym współczesnej jej koncepcji, wiedzą, że pytanie o wyjście z niewoli rozumu jest dla świadomości europejskiej bardzo kłopotliwe. Jest to jednocześnie pytanie o przedmiot, granicę i wartość naszego poznania (por. FeR 4-5) ${ }^{7}$. Bez filozoficznej czy wręcz metafizycznej eksplikacji poznania nie jest możliwe przedarcie się poza granice relatywizmu, który unieruchamia myślenie współczesnego człowieka. Jak mówić o współistnieniu wielu kultur w dziejących się procesach globalizacji, jak tworzyć jedność, która nie zabije wielości? Jak mówić o rozwoju człowieka, wychowaniu czy samowychowaniu, gdy prawda i fałsz stały się równoważne, gdy wolny rynek w świecie wartości ma być zasadą budowania życia poszczególnych osób i całych społeczności? Jak można mówić o sile, szczęściu człowieka, gdy ma on jedynie prawo do opinii, która może być co najwyżej jakimś wstępem, ale nigdy szczytem poznawczych możliwości człowieka? Dlatego właśnie nauka, a szczególnie filozofia, ponosi odpowiedzialność za zniewolenie człowieka, a sam naukowiec i filozof stali się niejednokrotnie barbarzyńcami, czyli tymi, którzy swoim działaniem naruszyli ludzką godność. Zabrakło im tego, co najcenniejsze - mądrości ${ }^{8}$. Zabrakło im mądrości, która daje blask prawdy, nawet gdy kuleje natura, która wspiera transcendentalną perspektywą wlanych cnót: wiary, nadziei i miłości.

\section{Jakie jest miejsce filozofii we współczesnej kulturze?}

Podczas gdy formułowanie odpowiedzi na pierwsze pytanie doprowadziło do zaakcentowania obecności filozofii w kulturze i jej relacji do nauki, pytanie powyższe otwiera nas na sprawę nie mniej istotną dla uzasadnienia mojej tezy, tj. na celowość uprawiania filozofii dziś, a więc zachęca do postawienia pytania bardziej podstawowego: czym jest w ogóle filozofia?

Patrząc na dzieje filozofii, można na owe pytanie odpowiedzieć na dwa sposoby. Jeden to wersja bardziej „klasyczna”, w drugim zaś znajdzie się trochę mniej tego, co w „klasycznej wersji” uznawano za mądrość. Chociaż obie wersje (klasyczna i nie-klasyczna) chcą widzieć w filozofie mędrca, w tej drugiej jego twarz czasem wykrzywia się w ironicznym uśmiechu i szelmowsko ,puszcza oko” do tych, którzy szukają w filozofii jakieś życiowej rady. „Chcecie prawdy?” - pyta Filozof i jak echo powtarza słowa, wypowiedziane kiedyś przez pewne-

${ }^{7}$ Por. postulaty stawiane tamże z M. A. Krapiec, O rozumienie filozofii, Lublin 1991 oraz tenże, Poznawać czy myśleć?, Lublin 1994.

${ }^{8}$ Zob. A. Lekka-Kowalik, Czy naukowiec może stać się rzecznikiem barbarzyństwa?, w: Z. J. Zdybicka, A. Maryniarczyk i inni (red.), Wierność rzeczywistości, Lublin 2001, s. 431-446. 
go Rzymianina (żołnierza, polityka i filozofa w jednej osobie), który, umywając ręce, symbolicznie strącał z siebie, spoczywającą na nim tylko przez chwilę odpowiedzialność za losy świata - ,prawda, czym ona jest?!” Następnie filozof-polityk trochę nostalgicznie dodaje - „Spójnością naszego myślenia, pragmatycznym wyborem czy społeczną umową?" - i ze zniechęceniem mruczy „idźcie do domu, prawdy nie ma albo wszystko jedno, co nią jest” - a odganiając się od natrętów, pointuje - „to zresztą, to samo”. Miny tych, którzy czekali na mądrą odpowiedź, muszą być nieszczególne. Jedni może odejdą z niesmakiem, inni z oburzeniem zakrzykną, „do diabła z takim filozofem!”, jeszcze inni, by nie czuć się zmanipulowanymi, udadzą, że coś jest w tej filozoficznej mowie i ze zrozumieniem pokiwają głowami.

Człowiek zawsze doświadczał rozwoju swego poznania, wyrazem tego był szacunek, jakim ludzie różnych kultur otaczali tych, którym było dane wiedzieć więcej. Od nich oczekiwano rady. Mądrość była praktycznym rozpoznawaniem tego, co w życiu należy czynić, a więc poznaniem, w którym było odniesienie do celu ludzkiego życia. Kultura starożytnej Grecji w ten wymiar ludzkiej mądrości nieodwracalnie wpisała filozofię. Filozofia nie była samą mądrością, ale jej teoretycznym filarem, bo, mówiąc o ostatecznych przyczynach rzeczywistości, mówiła o celu ludzkiego życia, hierarchii dóbr i ludzkiej wartości. W tym też sensie wspomagała roztropne działanie, służyła radą, jak przeżyć swoje życie szczęśliwie, choć nie podejmowała za nikogo decyzji.

Chrześcijaństwo doceniło sapiencjalny wymiar filozofii, ale ponad jej mądrość postawiło mądrość teologii, a ponad nimi mądrość jako dar Ducha Świętego. Uzasadnienie tych stopni mądrości, mogących być udziałem człowieka, leżało w gestii filozofii, która w XIII wieku, wznosząc się może na szczyty metafizycznej spekulacji traktatem De Veritate profesora paryskiego uniwersytetu, potomka książęcego rodu Akwinów, Tomasza, odpowiedziała na pytanie, dlaczego możliwe jest ludzkie poznanie i za autorytetami starożytności powtórzyła, że jego sens polega na uzgodnieniu się myśli ludzkiej z rzeczywistością. W możliwości tego uzgodnienia leżą natomiast podstawy obiektywnego porządku wartości i tego, że w ludzkim sumieniu pojawia się sprzeciw lub akceptacja wobec ludzkich decyzji (por. VS 54-64). O tej relacji porządku teoretycznego i praktycznego nie potrafili już pisać wielcy filozofowie epoki nowożytnej od wieku XV po kantowskie agnostyczne rozwiązanie, które czyniło z człowieka dyktatora wartości. Czasy późniejsze pozwoliły sprawdzić to rozwiązanie tak w wymiarze społecznej praktyki, jak i indywidualnego życia osób.

Kryzys współczesnej kultury, który jest związany z zastąpieniem w ludzkim działaniu normy personalistycznej utylitarystyczną, przekłada się na moralny niepokój czasów współczesnych, w których etyka ma się obyć bez prawdy, sprawiedliwość bez moralności, moralność bez Objawienia, a człowiek ciagle tropi swoją tożsamość i nie wie, kim jest ${ }^{9}$. W wymiarze osobowego życia jest to

9 Zob. B. Grodzieńska (red.), Człowiek w poszukiwaniu zagubionej tożsamości, Lublin 1987. 
jeszcze zrozumiałe, bo przychodząc na świat każdy dopiero zaczyna się rozglądać, choć chciałoby się powiedzieć „od czego rady starszych”, ,a gdzie wychowanie”. Gdy na sytuację popatrzy się jednak globalnie - historycznie, to staje się ona groteskowa. Człowiek na tej Ziemi chodzi nie od dziś, a to, co stanowi niszę jego życia, to jest kulturę, on sam wytworzył. Wygląda na to, że przestał panować nad swoim wytworem, bo nie umie go zracjonalizować, ocenić, nabrać do niego dystansu. Przestał być wolnym, swoje serce dał światu.

W momencie, gdy tak czy inaczej definiowany pożytek zastąpił prawdę, a tę zamianę współczesna kultura zawdzięcza filozofii pokartezjańskiej, pokantowskiej, które w tropieniu pewności poznania zanegowały klasyczną metafizykę (i takie jej pojęcia jak substancja, przyczyna, natura), ona sama (czyli kultura) zamiast stać się umocnieniem ludzkiego życia, coraz bardziej zaczęła obnażać jego słabość. Nic dziwnego, że współczesny człowiek czuje się zagubiony i zniechęcony. Nic dziwnego, że dziś mamy do czynienia z różnymi społecznymi patologiami czy chorobami psychicznymi i załamaniami nerwowymi ${ }^{10}$. Trudno mówić o zdrowych relacjach międzyludzkich i pokoju wewnętrznym osoby, gdy człowiek nie rozumie siebie, swojej natury (jeśli ją ma?). Skoro człowiek nie rozumie siebie, to jak ma rozumieć drugiego człowieka i przestrzeń, która jest między osobami ${ }^{11}$ ? Dlatego dziś wiele słów, które ludzkość znała od dawna, jest nieczytelnych albo zmieniło znaczenie, na przykład dialog stał się monologiem, dyskusja - wymianą poglądów bez jakiejkolwiek chęci szukania prawdy, a tolerancja stała się przyzwoleniem na rację mniejszości bez względu na to, czy ta racja jest prawdziwa czy nie. Żyjemy w kulturze indywidualistycznej, w której próbujemy sami uporać się ze swoją słabością.

Tracąc perspektywę transcendencji, próbujemy sami zmartwychwstać, sami się zbawić. Ezoteryka jest najprostszą intelektualno-mitologiczną techniką rozkładania parasola ochronnego nad ludzka słabością. Brak trzeba jakoś zabezpieczyć. Magia jest dziś w oświeconej Europie czymś łatwo dostępnym. Obok sztywnego rygoryzmu autonomicznej pedagogiki nieistnienia braku, której katolicka pedagogika miłości braku dawała odpór (na przykład system prewencyjny św. Jana Bosko czy innych wielkich wychowawców Kościoła), magia to propozycja, która łatwo zniszczy zatomizowaną społeczność indywidualistów.

Indywidualizm jako taki nie jest niczym złym. Wpisuje się bardzo naturalnie w indywidualność bycia osobą. Każdy jest sobą, a nie kimś drugim. Nawet najpiękniejsze wzorce wychowawcze, wzorce służebnej miłości bliźniego, są tylko drogowskazami. Żadna norma nie może zastapić praktyki kształtowania charakteru. Gdyby tak się stało, to uczeń nigdy by nie wydoroślał. Funkcja szkoły jest przecież inna. Ona wspomaga prowadzenie człowieka do dorosłości. W tym

${ }^{10} \mathrm{O}$ braku wewnętrznego uporządkowania człowieka, który daje znać różnymi zaburzeniami w życiu psychicznym, piszą psychologowie. Zob. np. A. A. Terruwe, C. W. Baars, Integracja psychiczna, Poznań 2002.

${ }^{11}$ Zob. K. Wojtyła, Mitość i odpowiedzialność, Lublin 1986. 
procesie wychowawczo oddziałują na człowieka wszystkie osoby, które spotyka w swym życiu (u kreacjonistów także osobowy Bóg), a wychowanek jest w tym procesie szczególnym przedmiotem. Szczególność jego bytowania polega na niezdeterminowaniu (ewolucjonistycznie lub kreacjonistycznie pojętym). Z jego wolnością musi liczyć się każdy wychowawca i on sam, człowiek-wychowanek. Proces wychowania staje się zintegrowany, gdy człowiek-wychowanek, biorąc swe życie odpowiedzialnie w swoje ręce, staje się dorosły. Gdy staje się autowychowawca. Zawsze jednak jako osoba jest podmiotem wszelkich procesów społeczno-kulturowych!

Indywidualizm wpisany w człowieczeństwo (w podmiotowość człowieka) jest więc czymś niekwestionowanym. Inaczej oczywiście opowie o nim kreacjonizm, a inaczej ewolucjonizm. Dla kreacjonisty wymiar indywidualności jest tak głęboki, jak creatio ex nihilo. Filozoficznie wyraża się to terminem dusza ludzka, czyli forma organizujacca materię do bycia ludzkim ciałem. I słowo „materia”, i słowo „forma” mają bardzo klasycznie metafizyczne znaczenie. Sięgają jeszcze rozwiązań przedkartezjańskich. Dusza nie jest więc tylko świadomością, wolą. Jest w swojej prostocie złożona (władze duchowe jako jej przypadłości). Jest aktem w porządku istoty, ale nie istnienia (metafizyka, na przykład tomistyczna tak o tym opowiada)! Bytowość bytu człowieka, jak i bytowość w ogóle nie wyczerpują się w byciu tylko na przykład Janem Kowalskim. Oprócz Jana K. po świecie chodzą też inni ludzie. Dlatego indywidualizm wyabsolutyzowany (wyrastający z idealistycznej metafizyki) staje się strasznym kłamstwem, które w wymiarze społecznym zatruwa przestrzeń dialogu nie bardziej niż kolektywistyczne rozwiązania płynące $\mathrm{z}$ pozytywistycznych antropologii.

Gdyby każdy z nas wziął balonik do ręki i w tym samym momencie na całym świecie wypuścilibyśmy te baloniki, to z nich nie powstałby jeden wielki balon. Tak jak balonik lecący do nieba, każdy z nas odbywa własną podróż przez życie wśród innych baloników. Ale ten obraz pokazuje tylko jeden wymiar naszego życia. Jeśli potraktujemy go jako jedyny, ułożymy na przykład teorię wychowania promującą naszą osobność. Będziemy wychowywać ludzi jako „samotne baloniki”. Czym stanie się wtedy przestrzeń wspólna, ta przestrzeń między tysiącami baloników? Co będzie znaczyło słowo: proszę, dziękuję, przepraszam? Może tylko: daj, należy mi się, mam prawo?

Obraz ma zawsze dużą siłę oddziaływania, ale jest metaforą sensów głębiej ukrytych. Filozofia posługuje się pojęciem osoby na oddanie sytuacji bytowej człowieka. Być osobą to być osobno, ale razem. Tę przestrzeń wspólnoty pokazuje każde działanie piękne kulturowo, które błyszczy blaskiem prawdy dobrze pojętego humanizmu. Człowiek nie jest sam, nie może być sam, ale musi także być sobą. Musi mieć szanse na realizowanie swojej indywidualności. Dzieci nie są własnością rodziców, nauczycieli, trenerów, polityków, naukowców. Żaden człowiek nie jest własnością drugiego człowieka. Jednak jesteśmy razem. Bez bycia razem nie narodzimy się, nie żyjemy i nie umieramy. Ile razy tracimy tę personalistyczną perspektywę, kultura staje się krzywym zwierciadłem naszej prywatnej świetności. 
Społeczne ideologie były praktycznym skutkiem takich właśnie rozwiązań, za którymi w głębi ukrywała się dyskusja filozofów nad niepozorną kwestią prawdy, pewności poznania. Owe ideologie, kierując życiem całych ludzkich zbiorowości, czasami przybrały formę antyhumanistycznych toatlitaryzmów. Totalitaryzm swoje źródło miał w nowożytnej antropologii filozoficznej, która, mówiąc najkrócej, rozerwała relację „osobno” od „razem” i wyakcentowała wartość jednej ze stron tej relacji. W tle tego procesu stało filozoficzne rozwiązanie prymatu woli nad rozumem. Dla tej woluntarystycznej proklamacji dyskusje o prawdzie były ważną inspiracją a głębiej jeszcze pierwsze pytanie, które wyznacza metodę pracy badawczej filozofii. Gdy pytanie o byt ustapiło pytaniu o poznanie, troskliwa mądrość filozofii dziwnie przestała łączyć sferę teorii i praktyki.

Gdy dalej nastąiło wyjęcie ludzkiego działania ze sfery racjonalności i prawdy, nic nie mogło już gwarantować uznania ludzkiej wartości. Bez blasku prawdy wolność zamienia się w samowolę i tyranię jednych ludzi nad innymi. Totalitaryzm może mieć postać jawną bądź zamaskowaną, to jest taką, w której bardzo dużo będzie się mówić o jednostce i jej wolności. Łacińskie słowo liber to polskie „wolny”, „nieskrępowany”. Liberalizm jako doktryna filozoficzna (także polityczna i ekonomiczna), wyrastająca z indywidualistycznej i naturalistycznej koncepcji człowieka, a podnosząca wolność osobistą (polityczną, gospodarczą) jednostki do rangi najwyższej, uderza w samego człowieka i to o tyle perfidnie, że cały czas odwołuje się do tego, co rzeczywiście czyni ludzkie działanie tak wyjątkowym w sferze wszystkich bytów, to jest do wolnej decyzji.

Żeby jednak decyzja mogła być wolna, wola musi odbyć dialog z rozumem, który „czyta” dobro osobowe ${ }^{12}$. Bez rozumienia celu swojego życia człowiek stanie się tylko „pyłkiem na wietrze”, a mgliste pragnienie mocy, pojawiające się jak tło, będzie rodziło tylko stany neurotyczne i niosło piętno tragizmu niespełnienia. Rozumienie braku jako części swojej mocy jest bardzo ważne. Metafizycznie brak można opisać zawsze jako zakotwiczony w dobru. Substancjalność człowieka-bytu-dobra stoi u podstaw braku. Termin „substancja” w klasycznej filozofii oznacza to, czemu z natury przysługuje istnienie w sobie, oznacza bytowe podłoże, rację tożsamości i względnej niezmienności. Przypadłość, chociaż jest już nie-istotną własnością czegoś, ale także jest realnym przedmiotem, z tym, że bytowo niesamodzielnym (na przykład rozum, wola, zmysły względem istotnych elementów człowieka: jego duszy i ciała). Relacja substancji i przypadłości bytudobra-osoby zakreśla sens rozumienia człowieka-podmiotu. Ona wyznacza ostatecznościową perspektywę ludzkiemu działaniu i wychowaniu. Wtedy „podniesiony" staje się też brak, którego świadome przeżywanie rodzi piękno wolności nowego człowieka. Człowiek, który nie żyje horyzontem transcendencji, będzie tylko dziwacznie „upiększał” swój brak. Ekshibicjonizm jak i chowanie głowy w piasek nic nie zmieniają. Koniec jest tylko końcem, i człowiek swego końca sam nie zmieni. Nawet jeśli w laboratoriach będzie zmierzał do wyprodukowania

${ }^{12}$ Zob. J. Woroniecki, Katolicka etyka wychowawcza, t. 1, Lublin 1986, s. 97-147. 
„post-człowieka”13. Dla każdego (tak twórcy „post-człowieka”, jak kreacjonisty) śmierć jest końcem. Czego?

Powracając do pytania postawionego $\mathrm{w}$ tej części mojego artykułu, to jest do pytania o miejsce filozofii we współczesnej kulturze, można by było dokonać przeglądu współczesnych nurtów filozoficznych czy poglądów znaczących filozofów XX i XXI wieku. Proponuję natomiast drogę krótszą, a zasadną ze względu na tezę tego tekstu, to znaczy przyjrzenie się tak zwanym standardom nauczania pedagogów filozofii zalecanym na przykład przez Ministerstwo Edukacji Narodowej. Pozwala to przyjrzeć się filozofii pod kątem jej podmiotowości (oczywiście też aspektywnie rozumianej). Przy całej bowiem narzędności filozofii, jak każdej wiedzy będącej bogactwem człowieka-osoby i służącej, jak każda nauka, człowiekowi w jego życiu, filozofia jest (nie każdy filozof się z tym zgadza!) wiedzą autonomiczną, tworem wolnego, racjonalnego, czyli osobowego bytu ludzkiego. Jej aspektywna podmiotowość wynika z jej celu. Do czego jest więc filozofia?

Filozofia nie raz była ancilam culturae. W swojej służebnej roli nie powinna jednak iść przeciwko rozumowi. Ludzki rozum w swojej potencjalności bycia prawym może tworzyć piękne dzieła, a w swojej deprawacji, podążając za ukrytym resentymentem, może usprawiedliwić wszystko. Rzeczywistość nie. Dlatego dzieła człowieka, jego oblicze, usta, jego ciało w swej nagości nie kłamią, choć w nim, jako autorze tych dzieł, podmiocie oblicza, ust i ciała, może być pełno kłamstwa! Warunkiem prawości działania człowieka jest prawość woli, którą zdobywa się przez wychowanie. Nieporządek w sferze pożądania będzie zawsze groził złem drugiemu człowiekowi. Uszanowanie przestrzeni dobra wspólnego wymaga cnoty, a ta jest trudem wprowadzania porządku rozumu w sferę tego, co nierozumne z natury, czyli w sferę ludzkich pożądań. Wychowanie wolitywności wymaga więc prawdy. Prawda praktyczna, wyrażająca się dobrem czynu, jest jednak inna niż prawda w wymiarze teoretycznym jako uzgodnienie myśli z rzeczywistością. Ta różnica, najkrócej mówiąc, będzie pracowała w człowieku jego decyzjami, poczuciem odpowiedzialności, sprawiedliwością, miłosierdziem, ale i doświadczanym faktem wyrzutów sumienia, nieumiejętnością podjęcia decyzji, skrupulanctwem, brakiem przebaczenia. Sumienie czasem ma wychowawca, nauczyciel, naukowiec i wychowanek, uczeń, student. By mówić o sumieniu, trzeba mówić o rozumie i jego współpracy z wolą, i dalej o władzach duszy i ich integralnej współpracy wynikającej z substancjalności człowieka. Dziś nauka nie wie, czy człowiek ma duszę, czy dusza ma takie władze jak rozum, wola, zmysły poznawcze i pożądania zmysłowe, wyrażające się cała gamą uczuć, wreszcie czy rozum jako władza pełni różne funkcje: teoretyczne, praktyczne, wytwórcze, czy wraz z wolą znaczy przestrzeń decyzji (na przykład jak w tomizmie). Czasem naukowcy wręcz wolą mówić o ukrytym determinizmie ludzkich działań. Filozofia

${ }^{13}$ Nowoczesny ewolucjonizm, opierając się na postępach biotechnologii, prognozuje przed wyginięciem rodzaju ludzkiego pojawienie się na Ziemi ,post-człowieka”. 
klasyczna wskazywała, że decyzje podejmuje każdy człowiek i tym się różni od zwierzęcia, którego działania są instynktowne. Dlatego człowieka można wychowywać, uczyć odpowiedzialności, a zwierzę tylko tresować, a za zwierzęce niepożądane działania czynić odpowiedzialnym człowieka (na przykład wymierzanie mandatów właścicielom zwierząt za szkody, które czynią ich pupile, ale także dewastacja środowiska naturalnego, zaburzenie ekosystemu to globalne nasze zadania i troska dzisiejszej ekologii).

Jeśli zakwestionujemy decyzyjność człowieka, nie obronimy jego podmiotowości. Nie obronimy przestrzeni wspólnego dobra, wspólnego zła i odpowiedzialności za nie. Nie obronimy się. Możemy oczywiście mówić, że nie wiemy jak jest, możemy stać na rozstajach dróg, kwestionując wszystko, możemy anarchistycznie demolować tradycję. Skoro jednak latamy w kosmos, używany energii jądrowej, prowadzimy badania nad genetyką, to coś przecież wiemy! Skoro tak dużo wiemy, to dlaczego przeżywamy tyle kłopotów na linii kontaktu z drugim człowiekiem. Zwierzęta chyba nie mają takich trudności. W każdej frustracji jest jednak jakaś jej przyczyna. Każde napięcie może być oczyszczające. Co jest w wielkich rozczarowaniach człowieka dziś? Czym obudzi się w przyszłości utajony gniew naszych wychowanków?

Relatywizm jest wygodny. Zawsze można powiedzieć, że o gustach nie rozmawiamy. Gust jest bardzo prywatny. Tak jak oblicze człowieka. Jakie jest oblicze człowieka dziś? Prywatność gustu obok prywatności decyzji jest niekwestionowaną sprawą. A co ze świadomością? Czy dziś jeszcze cokolwiek nas łączy? Czy wśród różnych podziałów nie zapomnieliśmy o przestrzeni wspólnej? Bo jak prywatne są gusty i decyzje, to ich owoce są już doświadczeniem międzyosobowym, bo nie da się wyjść człowiekowi z rzeczywistości świata. To kończy tylko śmierć.

Prywatność przestrzeni wolności, będąca faktem jego podmiotowości wobec podmiotowości drugiego człowieka i jego wolności, zniekształcona rodzi społeczne cierpienie i może nieść zagładę dla wielu podmiotów-osób. Jak osoba, jak rodzina, jak naród, jak ludzkość są podmiotami wobec świata przyrody, struktur społecznych, państwowych, międzypaństwowych, tak filozofia ma swoją podmiotowość wobec swoich władz ,ustawodawczych” i ,wykonawczych”. Jak w człowieku jego sercem, jego sędzią jest jego sumienie, tak podobnie jest w filozofii, gdy pyta o byt. Gdy zadaje swoje pytanie „dlaczego?” Bez tego pytania, bez metafizyki filozofia nie ma sumienia, nie ma swojej podmiotowości, nie ma serca. Jaką ma wtedy wartość? Kto ją szanuje?

Oczywiście, można dyskutować, czy wprowadzona tu figura „sumienia filozoficznego" nie jest zbyt daleko posuniętą metaforą. Czym jest więc sumienie filozofii? Czymś najważniejszym, czymś bez czego nie ma danego bytu (tu: filozofii). Z proponowanego polskim pedagogom programu nauczania filozofii wynika, że filozofia to głównie historia filozofii i trochę logika. Mamy więc sumienia historyczne i skrupulatne. $\mathrm{Na}$ ważne zagadnienia filozoficzne poświęca się stosunkowo mniej czasu. Jest oczywiście trochę aksjologii. Sumienie ideałów 
jest wiec przekazywane. To dobrze, bo bez tego trudno myśleć o przyszłości. Czym jednak są te idealne wartości? Dziedziny filozoficzne, które kiedyś się tym zajmowały, wśród których klasycznie wymieniano „filozofię pierwszą”, są przecież dziś w kształceniu pedagogów nieobecne. A filozofia człowieka? Również.

Jeśli dzisiejszy program zestawimy z bardziej klasycznymi wzorcami, to powstanie niemała konsternacja. Arystoteles, ojciec logiki, logikę nazwał tylko narzędziem nauki, a filozofia była poznawaniem rzeczywistości w świetle przyczyn. Sama historia filozofii należała oczywiście do ogólnej kultury filozoficznej, bo filozofia jako nauka nigdy nie była sprawą jednego człowieka (jak prywatny jest zawsze światopogląd), ale namysłem, w którym dialog ten, w perspektywie historycznej także, był bardzo ważny! Roli historii filozofii w uprawianiu filozofii nie można nie doceniać. Nie ma odpowiedzialnego filozofowania bez znajomości historii filozofii, jednak sama filozofia nie jest historią filozofii. Absurdalność tego widać w porównaniu z zastosowaniem takiej propozycji do innych nauk. Gdyby uprawianie jakiejkolwiek nauki ograniczyć do uczenia jej historii, przestałaby być ona poznawaniem rzeczywistości, a tylko historią ludzkich idei na dany temat, nie mówiąc już o tym, że przełożenie osiagnięć różnych nauk na technikę, które to przełożenie jest dla współczesnego człowieka czymś oczywistym, przestałoby takim być, bo wszelkie wytwory mogłyby mieć, co najwyżej, wartość muzealną!

Czy filozofia ma jeszcze coś do zaoferowania człowiekowi dziś? Co może dać pedagogice? Co wychowawcy? Jeśli nazywano ją kiedyś wiedzą sapiencjalna, to dlatego, że nie tyle uczyła zestawiać historyczne poglądy, skutecznie przekonywać, piętrzyć trudności i zastawiać intelektualne pułapki, zadziwiać sofistycznym myśleniem i wielką erudycją, ale dlatego, że zabiegała o poznanie prawdy w najgłębszych tajnikach rzeczywistości, że wchodziła w tajemnicę bytu i ludzkiego istnienia, że oddzielała to, co jest mitem, ideologią, co ma pozór prawdy, od tego, co prawdą jest, że odróżniała myśl od rzeczywistości, wytwór od bytu ${ }^{14}$. W czasach współczesnych, przy całej historyczności dwudziestu kilku wieków filozofii, bez dobrego przewodnictwa osoby rozumiejącej sens filozoficznego poznania i bez aktywnie uprawianej filozofii w duchu tego, czym jest ona ze swej natury (kreacjonizm czy ewolucjonizm?), wielość różnorodnych poglądów filozoficznych może pogłębiać tylko ogólny stan zagubienia studiującego filozofię, szczególnie pomocniczo (jak na pedagogice!). Ponadto, jeśli filozofia i filozofowie nie przemyślą kwestii dla siebie zasadniczych, to tak organizowana struktura studiów ideologicznie wręcz będzie zatwierdzać relatywizm aksjologiczny i pogłębiać kryzys współczesnej kultury (zob. FeR 1-6).

Jak w takiej filozofii znaleźć oparcie dla teorii wychowania? Jak odwoływać się w pracy nauczycielskiej do filozofii, która otwiera drogę irracjonalizmowi, która nie pozwala budować autorytetów, która z nauczyciela może, co najwyżej, czynić specjalistę w określonej dziedzinie, ale odmawia mu prawa bycia wycho-

${ }^{14}$ Zob. M. A. Krapiec, O rozumienie filozofii. 
wawca, bo jak mówić o wychowywaniu młodego człowieka, jeśli trudno określić, czym jest ludzka natura, a tym bardziej, co znaczy ją kształtować? Do czego mamy wychowywać? Ewolucjonista uczciwie chyba musi odpowiedzieć: nie wiem. Inaczej stworzy mit jakiegoś Nadczłowieka (post-człowieka?). Chrystus, mówiąc o ponownym narodzeniu, mówił o narodzeniu się z Ducha Świętego. W dzieło zbawienia zostaje człowiek włączony przez chrzest, ale to dopiero początek drogi. Ludzie często nie szanują wolności innych ludzi, ale Bóg nigdy. On stwarza nas, byśmy byli wolni, byśmy w sposób wolny Jemu odpowiedzieli. Dlatego chrześcijańska kultura w swej istocie nie jest kulturą automatów, ,zaprogramowanych chrztem maszyn". Dlatego chrześcijanin ciągle musi walczyć o swoje serce, o swoją wolność. Walczyć, by w drugim, w innym zobaczyć siebie. Złem jest wyzysk drugiego człowieka, ale złem jest też walka klas jako szerząca nienawiść do innego-bogatego. Złem jest zachłanność kapitalisty, który w drugim widzi tylko narzędzie do swojego bogactwa.

Cokolwiek by nie mówić o stanie współczesnej filozofii, jej kryzysie i słabości, człowiek nie może żyć w znaczeniowej pustce. Deklaracje pooświeceniowych filozofów o niemożliwości racjonalnego sięgania po najważniejsze dla człowieka pytania egzystencjalne nie zniechęciły ludzi do ich zadawania. Gdy metafizykę wyproszono z grona nauk, w społecznej roli metafizyków mógł wystąpić każdy. Dlatego w kulturze, która nie racjonalizuje metafizycznie pytań egzystencjalnych, każda mitologia może domagać się legislacji i gromadzić swoich wyznawców $^{15}$. Czy jednak w nich (to jest w mitologiach) ci, którzy odpowiadają za kształtowanie młodego pokolenia, mają znajdować swoje teoretyczne (to jest informacyjno-poznawcze) wsparcie? Chrześcijaństwo wśród licznych zadań-celów-śródków ma jeden niezmienny rys: miłość. Miłość nie-przyjaciół, miłość innych. Tak uczył Jezus. Filozofia chrześcijańska ma tłumaczyć tę prawdę. Prawdę o pięknie, godności INNEGO. Na tym polega też jej rola służebna wobec pedagogiki, a pedagogiki chrześcijańskiej w szczególności.

Na zakończenie chciałam powrócić do zdania z początku tej wypowiedzi, w którym mówiłam o możliwościach i granicach poznania wyznaczanych ludzką naturą. Bez świadomości tego, co nią jest, bez rozumienia nas samych (ludzi), żadna kultura by nie powstała, bo tym różnimy się od innych stworzeń, że swoją racjonalnością znaczymy swoje działania. W naszych sercach jest miłość lub nienawiść. Figura „serca” filozoficznie (tomizm) może być oddana słowem ,integracja wewnętrzna człowieka". Będzie w niej całe bogactwo przeżyć intelektualnych i wolitywnych, uczuciowość, będzie dotyk ręki, czułość spojrzenia, radość uśmiechu, muzyka porozumienia różnych języków miłości. Będzie duchowość głęboko wnikająca w ciało i cielesność zapraszająca Ducha. Czy ów Rzymianin sprzed wieków był dobrym retorem, skutecznym politykiem, czy jak żołnierz wiedział, czym jest prawda końca ludzkiego życia? Może dostrzegł, że ten dziwny Żyd, o którego losie przyszło mu administracyjnie zadecydować, nie zagraża

${ }^{15}$ Zob. S. Swieżawski, Istnienie i tajemnica, Lublin 1993. 
imperium, bo chce być tylko królem nie z tego świata? Patrząc na dzisiejszą kulturę, można próbować odtworzyć świadomość społeczna, ale trzeba też pytać o serce społeczeństwa „baloników”. A więc: „Gdzie jesteś Adamie?”

\section{If philosophy do harm to the teacher? Some remarks on lost identity of men and philosophy (Summary)}

Whatever you may say about the state of contemporary philosophy and its crisis, man has to keep asking about the sense of life and how to live. Today, we often consent to the impossibility to draw on man's most essential existential dilemma. We tend to rake up old myths to feel safe. The wisdom of philosophy is not of value. Why? Can people responsible for the formation of a young generation find support in philosophy? What is the value of Christian culture in man's formation? Love has always been present in the numerous tasks, goals and means Christianity offers. The love of enemies, the love of the others. That is what Jesus taught us to do. Christian philosophy is expected to clarify this truth; the truth about beauty, the dignity of the other. This is the role of philosophy if it assists pedagogy and Christian pedagogy in particular. 